\title{
The Influence of Behavior Financial and Financial Attitude on Investment Decisions With Financial Literature as Moderating Variable
}

\author{
Fangky Antoneus Sorongan
}

\section{ABSTRACT}

The goal of this research is to see how financial behavior, attitudes, and literacy affect student investment decisions. Students from South Jakarta serve as case studies in this study. This study is quantitative, meaning it uses numbers as a baseline. The information was gathered by an online questionnaire that was distributed to 110 people using a purposive sample technique. With the help of the SmartPLS application, the data analysis technique used was partial least square. Financial behavior, financial attitudes, and financial literacy all have a major impact on investment decisions, according to the findings of this study, however financial literacy cannot regulate investment decisions made by students in South Jakarta.

Keywords: Investment Decision, Financial Literacy, Financial Behavior, Financial Attitude.

\section{INTRODUCTION}

In the modern era which is more financially driven as a characteristic, leading to a dependence on the quality of life on the individual's capacity to manage financial affairs. Therefore, a person's level of knowledge regarding financial matters will make it easier for that person to make daily financial decisions. Potential investors will experience issues with financial products, services, and market conditions, but they will also be more likely to face financial hazards in the future. When someone buys securities such as stocks, then he can be said to be investing, because that person does not spend all his money to buy consumer goods today. The purpose of this delay in consumption is the hope to get a greater return in the future from the value of the delay. According to Ogunlusi \& Obademi (2021) investment is a sacrifice made now with the aim of getting greater benefits or results in the future.

To minimize the risk of investing, investors must be prepared to face the stock trading market. Investors must also have an estimate or research beforehand on the company whose shares will be bought or sold by the investor. In addition to skills and estimates for investment decision making, investors are also heavily influenced by behavior and attitudes. Behavior and attitudes here are behaviors and attitudes in terms of managing finances and financial literacy involved in it. Financial literacy, as individual financial knowledge, is also basic knowledge for everyone to avoid financial problems, because financial challenges can develop from financial management errors such as a lack of financial planning, as well as from income variables. These things happen because of the lack of financial literacy and individual experience.

Financial literacy, also called financial knowledge, is the community's mastery of various things in the financial world (Ouachani et al., 2021). The term "knowledge" refers to a person's level of understanding of personal finance issues, as measured by their grasp of numerous personal finance topics. Liebi (2020) shows that financial knowledge is a conceptual definition of financial literacy.

Investment decision making is the process of making decisions about several issues or problems and making choices between two or more investment alternatives. Therefore, good financial knowledge or financial literacy is very important to make investment decisions. Financial literacy is a prerequisite for everyone to avoid financial problems in the future. According to research by Robb \& Woodyard (2011), adequate financial literacy will have a positive impact on one's financial behavior, such as proper financial management or distribution. Everyone usually distributes money in several forms, such as personal consumption, savings, and investments. Among several forms of disbursement of funds, the type of disbursement of funds that is most useful for the future is the type of investment.

Financial behavior or financial behavior is explained as individual behavior when faced with financial decisions that must be made. Behavioral finance can also be interpreted as a psychology-based theory that aims to understand how emotions can affect investor behavior. Every individual must be faced with financial problems such as how much money to receive and what to spend. There are many cases out there that someone has financial problems because the money spent does not match the income they receive, this is because of how the individual behaves.

According to Rai et al (2019), financial behavior as a study of how psychology affects individual financial behavior. Someone who has good financial behavior tends to be wiser in managing the funds they have, for example, 
such as investing and recording expenses. Financial behavior and investment decisions are two interrelated things. According to (Çera et al., 2021), behavioral finance is a science that observes how an individual behaves when making financial decisions. This understanding explains that there is a person's psychological influence when making investment decisions.

A person's feelings regarding personal financial matters, as measured by replies to a statement or opinion, are referred to as financial attitude. Pankow (2003) defines financial attitudes as a mentality and a financial judgment. According to Ananda \& Mikhratunnisa (2020), there is a link between attitude and the severity of financial troubles. Therefore, it can be said that a person's financial attitude also affects the way a person manages his finances, including the decision to choose investment products. Financial attitudes directly shape a person to save or spend money. Financial attitudes and financial management practices that are wrong can cause financial problems.

In terms of financial understanding, someone who is more confident and reasonable affects more profitable investment selections. The use of a good financial mindset is the first step toward excellent financial management. It will be impossible for someone who does not have a healthy financial attitude to have a financial surplus as future savings, let alone investment capital (Kadoya \& Rahim Khan, 2020).

Some investors certainly expect a certain return and risk, some want a high return with a certain risk, but there are also those who want a certain return with a smaller risk. The investment chosen and the amount of money invested are strongly influenced by the investor's risk tolerance. Risk tolerance is the level of ability to accept investment risk. Every investor has a different tolerance level.

Ouachani et al (2021) suggest in their research that financial literacy is a factor that influences individual investment decisions. The same thing was also expressed by Kavita \& Suman (2019), that a person's interest in investing is influenced by his financial knowledge. This is justified by van Rooij et al (2011), in his research he showed that people with low financial literacy usually invest based on a desire or a momentary trend. Kamakia et al (2017) found that the financial literacy variable had a negative effect on investment decisions.

Budhiraja et al (2018) in their research stated that behavioral financial theory is very important for investors, according to his behavior and psychology are important keys in the investment decision-making process. This is in accordance with Kandpal \& Mehrotra's (2018) research, which found that when it comes to making sensible investing decisions, behavior is crucial. The same thing with research (Mudzingiri et al., 2018) research results prove that financial behavior affects investment decisions. In contrast to research (Kadoya \& Rahim Khan, 2020) which states that financial behavior variables have no effect on investment decisions.

Onodugo et al (2021) in their research prove that financial attitudes have a positive effect on investment decisions, in their research stating financial attitudes help in determining attitudes and behaviors related to finance such as management, budgeting and making investment decisions.
This is in line with the research of Dewi et al (2020) which states that there is a significant relationship between financial attitudes and one's investment decisions. Similarly, according to Madaan \& Singh's (2019) research, financial attitudes have a favorable and significant impact on investing decisions.

Researchers are interested in examining the Effects of Financial Literacy, Financial Behavior, and Financial Attitudes on Investment Decisions in light of the gap phenomena and the existing research gap.

\section{LITERATURE REVIEW}

\section{A. Financial Literacy}

Financial literacy, according to Brigham \& Houston (2009), is a component of human resources that can be leveraged to improve financial conditions. Financial literacy, according to Kamakia et al. (2017), is defined as the knowledge and understanding of financial concepts and risks, as well as the skills, motivation, and self-confidence needed to make effective financial decisions in order to improve one's financial status and participation in the economy.

Financial literacy, according to Fatoki and Oni (2014), is a person's ability to process economic data and make judgments about financial planning, financial accumulation, retirement, and debt. Financial literacy, on the other hand, is described by Kavita \& Suman (2019) as the ability to make sound judgments and decisions about the use and management of money.

\section{B. Financial Behavior}

The way a person treats, manages, and uses their money resources is referred to as financial behavior. Individuals who practice responsible financial conduct are more effective in managing their finances, such as creating a budget, starting investments, and meeting their financial responsibilities on time (Robb \& Woodyard, 2011). Financial conduct describes how a person acts when presented with difficult financial decisions. Someone who can make financial judgments will not have problems in the future and will be able to prioritize their requirements and goals (Chinen \& Endo, 2012).

Financial conduct is related to one's financial responsibility via managing one's funds, according to Mudzingiri et al (2018). Financial responsibility is the process of effectively managing money. The practice of controlling and utilizing financial assets is known as financial management.

\section{Financial Attitude}

Attitude Finance is the use of financial principles to generate and maintain value through good decision-making and resource management. The individual's financial attitude will help determine the individual's attitudes and behavior in terms of finances, both in terms of management, budgeting, and how individual decisions are made in selecting the type of investment to be taken. Financial attitude, according to Pankow (2003), is a state of mind, opinion, and judgment regarding money. Personal financial attitudes play a significant role in one's financial success or failure. 


\section{Investment Decisions}

Investment is an activity of placing capital in a particular business that aims to earn income. An investment decision is a policy taken on two or more alternative placements of capital with the hope of getting profits in the future (Madaan $\&$ Singh, 2019). The more the number of people who invest, the more investment decisions will be made such as how much investment the individual will make and when the investment will be implemented.

The projected rate of return, the level of risk, and the relationship between the two serve as the foundation for investment decisions. As compensation for the opportunity costs and danger of diminishing purchasing power owing to factors such as inflation, investors demand substantial returns from their investments. A more daring investor is willing to take on more risk in exchange for a better rate of return. Investors who do not wish to accept excessive risks in exchange for high profits, on the other hand, cannot anticipate big returns. Investors require investment information, which is a key aspect in selecting investment choices, in order to make investment selections. Investors can choose the best investment option from the various options based on the information supplied.

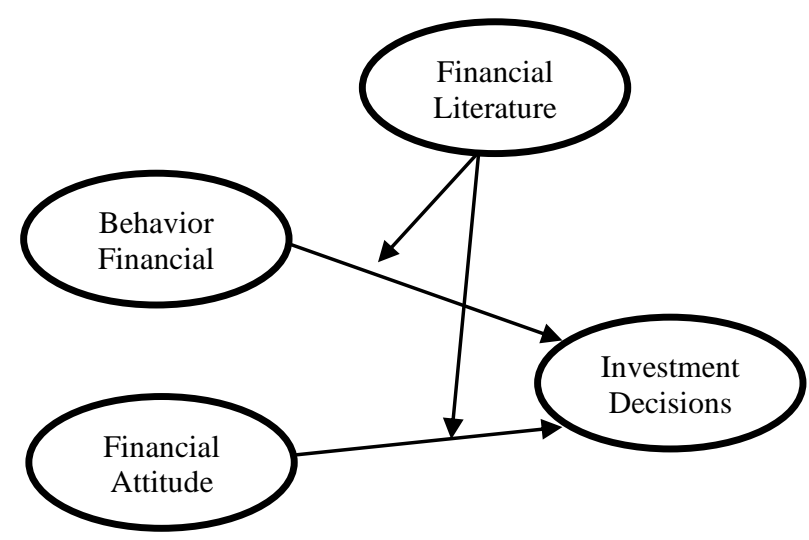

Fig. 1. Research Framework.

\section{Methodology}

The data will be collected utilizing survey methodologies and online questionnaires. The data will then be analyzed using the smartPLS application to run through a statistical model. With a total sample of 110 respondents, this study focused on millennial college students in South Jakarta. Financial knowledge, financial conduct, and financial views all have an impact on investment decisions, according to a list of statements presented to respondents.

\section{FINDING AND ANALYSIS}

\section{A. Validity and Reliability Test}

The validity test using the PLS-SEM model meets convergent validity, it can be said to be valid if the loading factor value of 0.7 . While the interpretation of the reliability of the variables can be said to be reliable if the Cronbach alpha and composite reliability values are $>0.60$.
TABLE I: VALIDITY TEST RESULTS

\begin{tabular}{|c|c|c|c|c|c|}
\hline \multicolumn{2}{|c|}{ Variable } & $\begin{array}{c}\text { Cronbach's } \\
\text { Alpha }\end{array}$ & rho_A & $\begin{array}{l}\text { Composite } \\
\text { Reliability }\end{array}$ & AVE \\
\hline \multicolumn{2}{|c|}{ Behavior financial } & 0.790 & 0.800 & 0.864 & 0.615 \\
\hline \multicolumn{2}{|c|}{ Financial attitude } & 0.810 & 0.811 & 0.875 & 0.637 \\
\hline \multicolumn{2}{|c|}{ Financial literature } & 0.859 & 0.869 & 0.904 & 0.701 \\
\hline \multicolumn{2}{|c|}{ Investment decisions } & 0.776 & 0.811 & 0.858 & 0.607 \\
\hline \multicolumn{6}{|c|}{ TABLE II: RELIABILITY TEST RESULTS } \\
\hline \multirow[b]{2}{*}{ Indicator } & \multicolumn{5}{|c|}{ Variable } \\
\hline & $\begin{array}{l}\text { Behavior } \\
\text { financial }\end{array}$ & $\begin{array}{c}\text { Financial } \\
\text { attitude }\end{array}$ & $\begin{array}{l}\text { Fin } \\
\text { lite }\end{array}$ & $\begin{array}{l}\text { ncial } \\
\text { ture }\end{array}$ & $\begin{array}{l}\text { nvestment } \\
\text { decisions }\end{array}$ \\
\hline BF1 & 0.821 & & & & \\
\hline BF2 & 0.845 & & & & \\
\hline BF3 & 0.791 & & & & \\
\hline BF4 & 0.773 & & & & \\
\hline FA1 & & 0.779 & & & \\
\hline FA2 & & 0.795 & & & \\
\hline FA3 & & 0.794 & & & \\
\hline FA4 & & 0.822 & & & \\
\hline FL1 & & & & 14 & \\
\hline FL2 & & & & 54 & \\
\hline FL3 & & & & 58 & \\
\hline FL4 & & & & 22 & \\
\hline ID1 & & & & & 0.716 \\
\hline ID2 & & & & & 0.884 \\
\hline ID3 & & & & & 0.886 \\
\hline ID4 & & & & & 0.796 \\
\hline
\end{tabular}

\section{B. Hypothesis Test}

By using the SmartPLS software, the results of the PLS Algorithm are as follows:

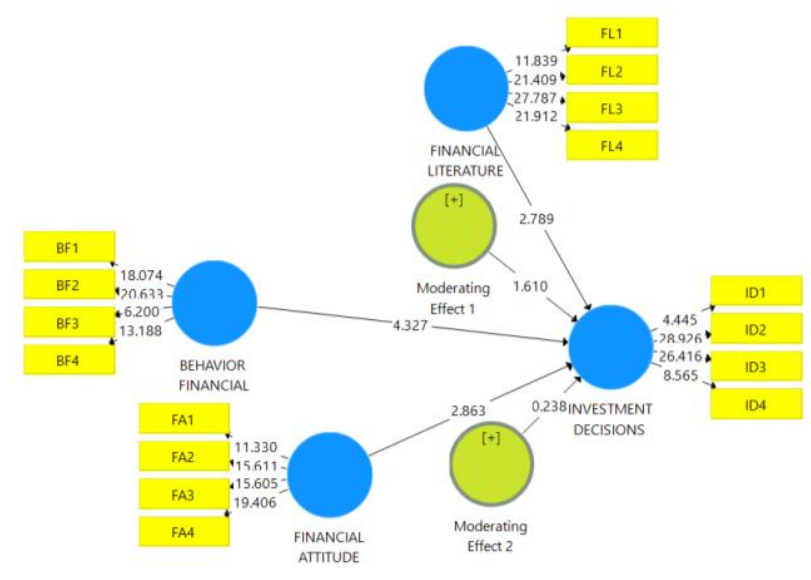

Fig. 2. Path Chart

TABLE III: RELIABILITY TEST RESULTS

\begin{tabular}{lcc}
\hline \hline variable & $\begin{array}{c}\mathrm{t} \text { statistics } \\
(\mid \mathrm{o} / \mathrm{stdev})\end{array}$ & $\begin{array}{c}\mathrm{p} \text { - } \\
\text { values }\end{array}$ \\
\hline Behavior financial $\rightarrow$ Investment decisions & 4.327 & 0.000 \\
\hline Financial attitude $\rightarrow$ Investment decisions & 2.863 & 0.004 \\
\hline Financial literature $\rightarrow$ Investment decisions & 2.789 & 0.005 \\
\hline Moderating effect $1 \rightarrow$ Investment decisions & 1.610 & 0.108 \\
\hline Moderating effect $2 \rightarrow$ Investment decisions & 0.238 & 0.812 \\
\hline
\end{tabular}

Based on Table III, it can be concluded that all three of this research, namely Financial Behavior, Financial Attitude and Financial Literacy have a significant effect on Investment Decisions, it can be proven from the results of data processing using SmartPLS because each variable has $\mathrm{P}$ Values $<0.05$ and T Statistics $>1.96$. Financial behavior is very important for investors because the influence of financial and psychological behavior is an important key in 
the investment decision-making process. The financial attitude will help the individual in determining the individual's attitude and behavior in terms of finance, both in terms of management, budgeting, or how the individual makes decisions in determining the form of investment to be taken. Meanwhile, the better students understand financial literacy, the better someone will be in managing their finances so that they can be used to assist decisions to make investments.

Based on table III, it can be seen that the moderating variable, namely financial literature, has $\mathrm{P}$ Values $>0.05$ and $\mathrm{T}$ Statistics $<1.96$. It can be concluded that the financial literature cannot moderate financial behavior and financial attitudes towards investment decisions.

\section{CONCLUSION}

Based on the results of the analysis carried out, there are several conclusions that can be drawn in this study, namely financial behavior has a significant effect on student investment decisions. Financial attitude has a significant effect on student investment decisions. The better one's financial attitude, the better one's attitude in managing their finances, including investment decisions. Financial literacy has a significant effect on student investment decisions. Financial literacy can help and increase knowledge and can help in managing finances or investment decisions. However, financial literacy cannot moderate financial behavior and financial attitudes towards investment decisions.

\section{REFERENCES}

Ananda, N. A., \& Mikhratunnisa. (2020). Financial Literacy Affects Financial Behavior Through Financial Attitude as an Intervening Variable. International Journal of Innovative Science and Research Technology, 5(12).

Brigham, E. F., \& Houston, J. F. (2009). Fundamentals of financial management, concise Edition. Cengage Learning.

Budhiraja, K., Raman, T. v, \& Bhardwaj, G. N. (2018). Impact of behavioral finance in investment decision making. International Journal of Civil Engineering and Technology (IJCIET), 1151-1157.

Çera, G., Khan, K. A., Mlouk, A., \& Brabenec, T. (2021). Improving financial capability: the mediating role of financial behaviour. Economic Research-Ekonomska Istrazivanja, 34(1). https://doi.org/10.1080/1331677X.2020.1820362

Chinen, K., \& Endo, H. (2012). Effects of Attitude and Background on Personal Financial Ability: A Student Survey in the United States. International Journal of Management, 29(1).

Dewi, V. I., Febrian, E., Effendi, N., \& Anwar, M. (2020). Financial literacy among the millennial generation: Relationships between knowledge, skills, attitude, and behavior. Australasian Accounting, Business and Finance Journal, 14(4) https://doi.org/10.14453/aabfj.v14i4.3

Fatoki, O., \& Oni, O. (2014). Financial literacy studies in South Africa: Current literature and research opportunities. Mediterranean Journal of Social Sciences, 5(20). https://doi.org/10.5901/mjss.2014.v5n20p409

Kadoya, Y., \& Rahim Khan, M. S. (2020). Financial literacy in Japan: New evidence using financial knowledge, behavior, and attitude.

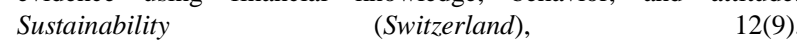
https://doi.org/10.3390/su12093683

Kamakia, M. G., Mwangi, C. I., \& Mwangi, M. (2017). Financial Literacy and Financial Wellbeing of Public Sector Employees: A Critical Literature Review. European Scientific Journal, ESJ, 13(16). https://doi.org/10.19044/esj.2017.v13n16p233

Kandpal, V., \& Mehrotra, R. (2018). Role of Behavioral Finance in
Investment Decision - A Study of Investment Behavior in India. International Journal of Management Studies, V(4(6)). https://doi.org/10.18843/ijms/v5i4(6)/06

Kavita, \& Suman. (2019). Determinants of financial inclusion in India: A literature review. Indian Journal of Finance, 13(11). https://doi.org/10.17010/ijf/2019/v13i11/148417

Liebi, L. J. (2020). The effect of ETFs on financial markets: a literature review. Financial Markets and Portfolio Management, 34(2). https://doi.org/10.1007/s11408-020-00349-1

Madaan, G., \& Singh, S. (2019). An analysis of behavioral biases in investment decision-making. International Journal of Financial Research, 10(4). https://doi.org/10.5430/ijfr.v10n4p55

Mudzingiri, C., Muteba Mwamba, J. W., \& Keyser, J. N. (2018). Financial behavior, confidence, risk preferences and financial literacy of university students. Cogent Economics and Finance, 6(1). https://doi.org/10.1080/23322039.2018.1512366

Ogunlusi, O. E., \& Obademi, O. (2021). The Impact of Behavioural Finance on Investment Decision-making: A Study of Selected Investment Banks in Nigeria. Global Business Review, 22(6). https://doi.org/10.1177/0972150919851388

Onodugo, C., Onodugo, I., Ogbo, A., Okwo, H., \& Ogbaekirigwe, C. (2021). Moderating role of social capital on the effect of financial behavior on financial inclusion. Problems and Perspectives in Management, 19(3). https://doi.org/10.21511/ppm.19(3).2021.41

Ouachani, S., Belhassine, O., \& Kammoun, A. (2021). Measuring financial literacy: a literature review. In Managerial Finance (Vol. 47, Issue 2). https://doi.org/10.1108/MF-04-2019-0175

Pankow, D. (2003). Financial Values, Attitudes and Goals, North Dakota State University Fargo, North Dakota, 58105.

Rai, K., Dua, S., \& Yadav, M. (2019). Association of Financial Attitude, Financial Behaviour and Financial Knowledge Towards Financial Literacy: A Structural Equation Modeling Approach. FIIB Business Review, 8(1). https://doi.org/10.1177/2319714519826651

Robb, C. A., \& Woodyard, A. S. (2011). Financial knowledge and best practice behavior. Journal of Financial Counseling and Planning, 22(1), 60-70.

van Rooij, M., Lusardi, A., \& Alessie, R. (2011). Financial literacy and stock market participation. Journal of Financial Economics, 101(2), 449-472.

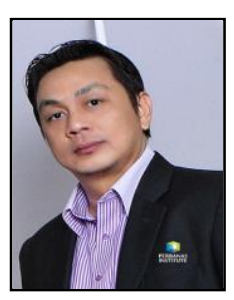

Fangky Antoneus Sorongan, ST., MM is a researcher and senior lecturer at the Faculty of Economics and Business, Perbanas Institute Jakarta. Graduated from the Informatics Engineering degree program from Atmajaya Catholic University, Yogyakarta, Indonesia. Graduated from the Master of Management program in Finance and Banking from the postgraduate Perbanas Institute. The research focus is in the fields of Banking Finance, Capital Markets and Information Technology for Business. 